\title{
ВПРОВАДЖЕННЯ STЕМ-ОСВІТИ В ІНКЛЮЗИВНЕ СЕРЕДОВИЩЕ НОВОї УКРАїНСЬКОї ШКОЛИ
}

0. Плужник, ДВНЗ «Переяслав-Хмельницький державний педагогічний університет імені Григорія Сковороди», м. Переяслав-Хмельницький, Україна ORCID iD: orcid.org/0000-0001-8780-8288 oks.pluzhnik1@ gmail.com

У статті розглянуто сутність STEM-освіти, в основі якої лежить не володіння теорією, а вміння використовувати свої знання на практиці. Визначено важливе значення STEMосвіти у роботі 3 учнями, що мають особливі освітні потреби. Зокрема, STEM-освіта забезпечує особливим дітям доступність, різноманітність та динамічність навчання, роботу в команді, можливість застосування отриманих знань у реальному житті, розвиток критичного мислення, впевненість у власних можливостях, прямий шлях від навчання до кар'єри. 3'ясовано, що вкрай необхідно під час впровадження STEM-освіти розвивати в учнів «мейкерські» здібності, які сприятимуть кращому втіленню в життя ідей новітніх технологій. Одним із видів «мейкерства» у початковій школі може бути давній вид мистецтва оригамі. Заняття оригамі добре впливають на особливих дітей та містять величезний корекційний потенціал.

Ключові слова: STEM-освіта, діти з особливими освітніми потребами, мейкерство, оригамі.

0. Плужник, ДВНЗ «Переяслав-Хмельницкий государственный педагогический университет имени Григория Сковороды», г. Переяслав-Хмельницкий, Украина

Внедрение stem-образования в инклюзивную среду новой украинской школы

В статье рассмотрено сущность STEM-образования, в основе которой лежит не владение теорией, а умение использовать свои знания на практике. Определено важное значение STEM-образования в работе с учащимися, которые имеют особые образовательные потребности. В частности, STEM-образование обеспечивает особенным детям доступность, разнообразие и динамичность учебы, работу в команде, возможность применения полученных знаний в реальной жизни, развитие критического мышления, уверенность в собственных возможностях, прямой путь от обучения к карьере. Выяснено, что крайне необходимо, при внедрении STEM-образования, развивать в учениках «мейкерские» способности, способствующие беспрепятственному перевоплощению в жизнь идей новейших технологий. Одним из видов «мэйкерства» в начальной школе может быть древний вид искусства - оригами. Занятия оригами хорошо влияют на особых детей и содержат огромный коррекционный потенциал.

Ключевые слова: STEM-образование, дети с особыми образовательными потребностями, мейкерство, оригами. 
0. Pluzhnik, Teacher of the department of pedagogy, theory and primary education PereiaslavKhmelnytskyi Hryhorii Skovoroda State Pedagogical University, Pereiaslav-Khmelnytskyi, Ukraine Implementation of stem education in the inclusive environment of the new ukrainian school The article discusses the essence of STEM-education, which is based not on theory, but on the ability to use their knowledge in practice. When STEM-education, the usual form of teaching for us is changing, when the lesson is built around a teacher. According to the STEM methodology, the focus is on the practical problem. Possible ways to implement the idea of STEM education are integrated lessons of different types, design and research activities. The basis of STEM-education is person-oriented learning. The importance of STEM-education in working with students with special educational needs is determined. In particular, STEMeducation provides special children with the availability, diversity and dynamism of learning, teamwork, the ability to apply their knowledge in real life, the development of critical thinking, self-confidence, the direct path from education to careers. It was found that it is extremely necessary, when introducing STEM-education, to develop in students «meikerskie» abilities that contribute to the smooth reincarnation of the ideas of the latest technologies. One of the «maker» types in elementary school can be an ancient form of art - origami. Origami classes have a good effect on special children and contain a huge correctional potential. Keywords: STEM-education, children with special educational needs, maker, origami.

Актуальність проблеми дослідження. Стрімкий розвиток IT-галузі, нанотехнологій виявляє потребу в досвідчених фахівцях, а отже, виникає гостра освітня потреба у якісному навчанні сучасних учнів природничих та технічних дисциплін математики, фізики, хімії, інженерії, програмування. Освіта має відповідати сучасним тенденціям розвитку суспільства, сприяти підвищенню конкурентоспроможності національної науки, розвивати нове покоління новаторів і наукових мислителів.

Класичний підхід до освіти вже не задовольняє потреби суспільства, що стрімко розвивається. Традиційний університет цілком може підготувати чудових викладачів філософії або історії, але для механіків, інженерів, винахідників потрібен інший стиль отримання і застосування нової інформації, який повинен бути доступним ще 3 дитинства. Такий підхід може не лише допомогти вчасно розкрити таланти і здібності юних інноваторів, але й дати можливість наблизитися до природничих наук. 3 кожним роком потреба в спеціалістах технічних професій буде рости, а їх брак ми відчуваємо вже сьогодні.

Аналіз останніх досліджень та публікацій. Теоретико-методологічне проектування засад STEM-освіти, координацію діяльності групи науковців та педагогів-практиків з питань науково-методичного забезпечення STEM-освіти, популяризацію STEM ідеології, аналіз відповідного закордонного досвіду виконує відділ STEM-освіти на базі ДНУ «Інститут модернізації змісту освіти».

Дослідженням теоретичних основ та сучасного стану впровадження STEMосвіти в Україні займаються вітчизняні науковці: О. Барна, Н. Балик, І. Василашко, Г. Войтків, Н. Гончарова, С. Горбенко, С. Кириленко, О. Коваленко, О. Лозова, О. Патрикеєва, I. Савченко, I. Стеценко, I. Чернецький та інші. 
Однак під час дослідженні наукових публікацій у цій галузі, ми виявили недостатне вивчення проблеми впровадження STEM-освіти в інклюзивне середовище Нової української школи, хоча ця тема в період сучасних освітніх реформ, на нашу думку, дуже актуальна.

Мета статті - розглянути суть STEM-освіти, визначити переваги STEMосвіти у роботі з учнями, що мають особливі освітні потреби (ООП).

Виклад основного матеріалу. Одним із актуальних напрямів інноваційного розвитку природничо-математичної освіти є STEM-орієнтований підхід до навчання. В Україні ця тенденція тільки починає набирати обертів. Через багатогранність та складність цього процесу потрібно багато часу для розв’зання проблем, пов'язаних із упровадженням освітніх програм у навчальні заклади.

Абревіатура STEM розшифровується як Science (Наука), Technology (Технологіi), Engineering (Інженерія) та Mathematics (Математика). При цьому дані дисципліни вивчаються не окремо, як ми звикли, а у комплексі. STEM-освіта розкриває учням точки дотику різних дисциплін. Коли в учнів є можливість застосувати тему з одного предмета до теми іншого, вони отримують більш глибоке розуміння концепції і починають розуміти ï важливість. Дитина не просто ознайомлює з новими напрямами розвитку точних наук та інженерії, а вчиться реалізовувати вивчене на практиці.

STEM-освіту часто називають «навчанням навпаки». Ланцюжок «від теорії до практики» у STEM зазвичай зворотний: спочатку - гра, придумування та майстрування пристроїв і механізмів, конструювання, а вже потім - опанування теорії і нових знань.

За таких умов, на перший план виходить не володіння теорією, а вміння використовувати свої знання на практиці. Уроки стають практичними заняттями, які демонструють можливості застосування теоретичних знань у конкретних ситуаціях. Розробляючи моделі, створюючи проекти, діти аналізують інформацію, співвідносять ㄲï з наявним досвідом і знаннями. Така система освіти навчає жити в реальному швидкоплинному світі, вміти реагувати на зміни, критично мислити, творчо розвиватися.

При STEM-освіті змінюється звична для нас форма викладання, коли урок побудований навколо вчителя. За STEM-методикою, у центрі уваги знаходиться практичне завдання чи проблема. Єдине, що має значення - здатність розв’язувати проблеми. Учні вчаться знаходити шляхи вирішення не в теорії, а шляхом спроб та помилок [4].

Можливими шляхами реалізації ідеї STEM освіти є інтегровані уроки різного виду (горизонтальної, вертикальної, наскрізної, різновікової інтеграції), проектна та дослідницька діяльність, де суворі наукові концепції поєднуються із захоплюючими уроками.

В основу STEM-освіти покладено особистісноорієнтоване навчання, що доцільно використовувати у навчанні дітей з особливими освітніми потребами. Як відомо, такі учні показують значно нижчі досягнення у науці, ніж їхні однолітки. Причинами цього $є$ серйозні труднощі з академічними навичками (наприклад, читання, математика і письмо), проблеми з поведінкою, недостатне 
розуміння основних концепцій теорії. Саме STEM-освіта може допомогти подолати ці проблеми та труднощі.

Розглянемо детальніше переваги STEM-освіти у роботі з учнями, що мають особливі освітні потреби (ООП):

- Доступність навчання. Починаючи 3 простих конструкцій (наприклад, LEGO) й закінчуючи запрограмованими роботами, дитина крок за кроком опановує основи фізики, механіки й програмування. Проводячи розважальні експерименти, учні легко починають розуміти складні формули, запам'ятовувати терміни, що дуже важливо для особливих дітей.

- Різноманітність та динамічність навчання. STEM-навчання ндає учням змогу переміщуватись по класу під час уроку. Це значно зменшує втомлюваність особливих дітей, дає змогу робити перерви. В процесі такого навчання учень отримує набагато більше автономності. Дитина шукає різні способи розв'язування задач, виходячи за межі шаблонів.

- Робота в команді. Під наглядом педагога діти вчаться працювати в команді, домовлятися та об'єднувати зусилля для розв'язання складних завдань. Для STEM учні поділяються на групи, що дає змогу дітям з ООП працювати на рівних зі своїми однолітками та навчатися відповідальності. Діти вчаться допомагати один одному. Робота у групах значно зменшує стрес і занепокоєння особливих учнів, адже, дитина не сама відповідає за результат - відповідальність несе уся група. Особлива дитина поступово вчиться відповідальності, спираючись на підтримку групи.

- Застосування отриманих знань у реальному житті. Часто діти просто не розуміють, як саме вони можуть застосувати знання з точних та природничих наук у подальшому, тому і зацікавленість не надто велика. STEM демонструє, як можна використати отриману інформацію в житті. Дитина вчиться спиратися на факти та перевіряти на практиці свої припущення. Так формується навичка логічного мислення, що грунтується на знанні закономірностей.

- Розвиток критичного мисления. STEM-освіта невід'ємно пов'язана з критичним мисленням та спрямована на його розвиток. Учні на основі отриманного досвіду, аналогій та узагальнень мають навчитися самостійно орієнтуватися, навіть у складних ситуаціях, та розв'язувати проблеми без сторонньої допомоги.

- Упевненість у власних можливостях. Створюючи цікаві проекти, діти з особливими потребами не просто навчаються, а ще й підвищують власну самооцінку. Так, вони стають білыш упевненими у собі та завзято досягають поставленої мети.

- Прямий шлях від навчання до кар'єри. Як відомо, багато випускників вишів, які мають обмежені можливості, не можуть знайти роботу. Тому краще, якщо ще у школі дитина буде розуміти, чого їй хотілося б найбільше. STEM відкриває для цього безліч пропозицій. Адже, вже зовсім скоро більшість затребуваних спеціальностей потребуватимуть саме STEM-знань. Навіть, якщо діти не оберуть у подальшому технічну професію, вони будуть цілком готові до нових технологій, тому що STEM-грамотні громадяни краще підготовлені для сучасних викликів суспільства. Дитина з порушеннями мови, слуху чи з обмеженими фізичними можливостями цілком добре може володіти комп'ютерними технологіями, тому починати треба якомога раніше. 
Щоб спонукати учнів до навчання та підтримувати тривалу й стійку зацікавленість, необхідно планувати посильні для кожного віку проекти та форми роботи. Оскільки багато учнів розчаровуються в процесі вивчення складного STEM-матеріалу, важливо дотримуватися наступності та етапності. Упровадження напряму STEM у закладах освіти повинно відбуватися за такими етапами:

1. У початковій школі: основне завдання - стимулювання допитливості та підтримка інтересу до навчання і пошуку знань, мотивація до самостійних досліджень, створення простих приладів, конструкцій тощо, наприклад, шляхом проведення навчальних екскурсів, днів науки, творчості, винахідництва.

2. У середній школі: основне завдання - викликати у дитини стійку цікавість до природничо-математичних наук: залучити до дослідництва, винахідництва, проведення інтегрованих уроків, тематичних тижнів, навчальних практик, реалізація міждисциплінарних проектів, участь у спеціалізованих гуртках, конкурсах, фестивалях.

3. У старшій школі: основне завдання - сприяння свідомому вибору подальшої освіти STEM профілю. Наприклад, поглиблена підготовка з груп предметів STEM (профільне навчання), освоєння наукової методології [1, 3-8].

Украй необхідно під час упровадження STEM-освіти розвивати в учнях «мейкерські» здібності, які сприятимуть кращому втіленню у життя ідей новітніх технологій. Мейкер - це людина, яка щось створює. Мейкерські здібності (уміння робити щось своїми руками) є практично в усіх. Починати треба з малого, а потім поступово переходити до робототехніки та 3-D друку. Сучасні діти мають у своєму арсеналі чимало онлайн джерел і цілком доступні інші ресурси: майстер-класи, творчі гуртки, невеличкі майстерні [2, 89].

Одним із видів «мейкерства» у початковій школі може бути давній вид мистецтва - оригамі. Багато хто вважає, що оригамі це забава, за допомогою якої люди створюють різні фігури, але дуже багато в оригамі пов'язано з математикою, геометрією. У процесі складання фігур оригамі діти вчаться легко орієнтуватися в просторі та на аркуші паперу, ділити ціле на частини, знаходити вертикаль, горизонталь, діагональ. За допомогою оригамі можна вивчити такі поняття як: точка, лінія; горизонтальні, вертикальні, похилі лінії; паралельні прямі; діагональ; квадрат, прямокутник; всі види трикутників; симетрію, однакові фігури. Отже, коли учні виконують найпростішу дію з аркушем паперу, наприклад, складають його по вертикалі або діагоналі, вони вже вирішують завдання на побудову. Оригамі - це простий процес моделювання та створення власного продукту, що є важливим для початкового етапу STEM-освіти.

На нашу думку, оригамі варто застосовувати у початковій школі для навчання дітей з ООП. Заняття оригамі добре впливають на таких дітей та мають величезний корекційний потенціал. Адже, заняття оригамі розвивають здатність працювати руками, контролюючи їх свідомістю; розвивають дрібну моторику i точні рухи пальців; розвивають окомір; мають емоційно-розвантажувальний характер, а одночасно і стимулюють естетичний та інтелектуальний розвиток та, головне, абсолютно безпечні. У процесі конструювання у дитини виникає необхідність співвіднесення наочних символів (показ прийомів складання) зі словес-

«ОСОБЛИВА ДИТИНА: навчання і виховання», № 1, 2019 
ними (пояснення прийомів складання) та перенесення їх значення у практичну діяльність (самостійне виконання дій).

Висновки і перспективи подальших розвідок у цьому напрямі. В основу STEM-освіти покладено особистісноорієнтоване навчання, що доцільно використовувати під час навчання дітей з особливими освітніми потребами. Як відомо, такі учні показують значно нижчі досягнення в науці, ніж їхні однолітки. Причинами цього є серйозні труднощі з академічними навичками (наприклад, читання, математика і письмо), проблеми з поведінкою та недостатнє розуміння основних концепцій теорії. Саме STEM-освіта може допомогти подолати ці проблеми та труднощі. Отже, STEM-освіта доцільна у будь-якому класі, для всіх дітей з різними можливостями та з різними типами засвоєння інформації, зокрема для дітей з ООП.

Результатом STEM-освіти буде всебічно освічена особистість з креативним мисленням, готова до експериментів, постійного навчання та зміни професійної діяльності. Саме така молодь найближчим часом матиме значний попит на ринку праці в сучасному високотехнологічному світі.

Стаття не містить вичерпних відповідей на питання освіти дітей з ООП в Новій українській школі, тому перспективи подальших розвідок полягатимуть у пошуку нових шляхів та рішень для забезпечення якісної освіти таких дітей.

\section{ЛITEPATУPA}

1. Барна О. В. Впровадження STEM-освіти у навчальних закладах: етапи та моделі/ O. В. Барна, Н. Р. Балик // STEM-освіта та шляхи їі впровадження в навчально-виховний процес: збірник матеріалів I регіональної науково-практичної веб-конференції, Тернопіль, 24 травня 2017 р. - Тернопіль: ТОКІППО, 2017. - С. 3-8.

2. Царинна Л. Г. STEAM-освіта - новий тренд у світі мистецтва / Л. Г. Царинна // STEMосвіта як перспективна форма інноваційної освіти в Україні: матеріали обласної науково-практичної інтернет-конференції, автор-упорядник Ю. М. Зоря. Черкаси : ЧОІПОПП, 2018. - 117 с.

3. Grace Villanueva, Mary $\mathcal{E}$ Taylor, Jonte $\mathcal{E}$ Therrien, William E $\mathcal{F}$ Hand, Brian. (2012). Science education for students with special needs. Studies in Science Education. 48. 187-215. 10.1080/14703297.2012.737117.

4. RoboSchool. Режим доступу: http://roboschool.info/2017/06/21/stem-osvita-shchovono-take-i-chomu-zminiuie-doliu-nashykh-ditei

5. 7 Big Ideas for Teaching Inclusive Classrooms. Режим доступу: https://sites.google.com/ site/teachinginclusively/home/inclusive-education-in-stem

\section{REFERENCES (TRANSLATED AND TRANSLITERATED)}

1. Barna O.V.( 2017). Vprovadzhennia STEM-osvity u navchalnykh zakladakh: etapy ta modeli / O. V. Barna, N. R. Balyk // STEM-osvita ta shliakhy yii vprovadzhennia v navchalno-vykhovnyi protses: zbirnyk materialiv I rehionalnoi naukovo-praktychnoi veb-konferentsii, Ternopil, 24 travnia 2017 r. - Ternopil: TOKIPPO,- S. 3-8[In Ukrainian].

2. Tsarynna L. H. (2018) STEAM-osvita - novyi trend u sviti mystetstva / L. H. Tsarynna // STEM-osvita yak perspektyvna forma innovatsiinoi osvity v Ukraini: materialy oblasnoi naukovopraktychnoi internet-konferentsii, avtor-uporiadnyk Yu. M. Zoria. Cherkasy : ChOIPOPP. - 117 s.[In Ukrainian]. 